\title{
Um paradoxo entre o existir e o resistir: a moda de viola através dos tempos
}

\author{
RAFAEL MARIN DA SILVA GARCIA I
}

\section{Introdução: a moda de viola enquanto gênero da música caipira}

$\mathrm{N}$

O PERCURSO histórico podemos observar de forma bastante clara a influência que elementos não tradicionais exerceram sobre a grande maioria dos gêneros considerados tradicionais da música caipira, principalmente se levarmos em consideração os avanços dos processos de mundialização da cultura e a chegada da indústria fonográfica no país. Além de uma gradativa mudança na temática das letras da música caipira, que passaram a incorporar assuntos relacionados à vida urbana, refletindo inclusive o próprio processo migratório, houve também uma mudança significativa na instrumentação desses gêneros mais tradicionais. Aos poucos, ritmos como toada, valseado, cururu, arrasta-pé, querumana, entre tantos outros, passaram a incorporar instrumentos modernos em sua instrumentação, como bateria, contrabaixo e até mesmo guitarra havaiana.

Em meio a um cenário de profundas transformações culturais, a moda de viola foi o gênero da música caipira que, mesmo depois de inserida na indústria fonográfica, manteve suas características tradicionais, no que diz respeito tanto às temáticas quanto à instrumentação. Esse é provavelmente o principal motivo que faz que a moda de viola seja considerada um dos principais símbolos da música caipira tradicional, remetendo consequentemente à construção de uma ideia de identidade caipira genuína.

A mesma ideia que discrimina um bloco de ritmos e instrumentos, atribuindo-lhes características que remetem a uma noção de identidade caipira (ou seja, à separação entre, de um lado, o que é genuinamente "tradição" e, de outro, o que "vem de fora”), estabelece também uma hierarquização entre o que consegue expressar com maior completude os signos de identidade e o que só o consegue imperfeitamente. Neste caso, encontram-se, como ritmos, a catira e a moda de viola e, como instrumentos, a viola e o violão, entre os itens mais valorizados por compositores, produtoras e consumidores da música caipira. Tanto é assim que, a partir de determinado momento, a moda de viola e a própria viola passam a exigir, como dado valorativo, uma marca cultural que as caracterizou como "moda caipira" e "viola caipira". (Pimentel, 1997, p.198, grifo do autor) 
Esse status que a moda de viola possui entre os gêneros da música caipira se deve também pelo fato de ela evidenciar muitos dos impasses, dos dilemas e das angústias do homem do campo, sendo utilizada como ferramenta de denúncia e crítica a processos de exclusão e opressão social, enaltecendo a humildade e a honestidade enquanto virtudes humanas e desmoralizando a ostentação de símbolos de riqueza e de má conduta, como a arrogância, a prepotência, a soberba, a inveja e a desonestidade. É a moda de viola que, por excelência, traz nos enredos de suas narrativas temáticas cujo principal objetivo é transmitir aos ouvintes algum ensinamento de conduta ética ou uma lição de vida.

A moda-de-viola é um outro gênero praticado e valorizado pelos violeiros piracicabanos. É tida, por vários deles, como o exemplo da "verdadeira música caipira", e sempre que eles querem se referir ao que não é música caipira ou sertanejo-raiz, eles citam duplas midiáticas que não cantam modas-de-viola. Esse caráter de símbolo da música caipira fica claro quando observamos que a expressão moda-de-piola, ou simplesmente moda, é abrangente com relação aos outros gêneros da música caipira. "Tocar uma moda" pode significar tocar uma moda-de-viola, mas, também, qualquer gênero caipira, como um cururu, por exemplo. (Paula Oliveira, 2004, p.127-8, grifos do autor)

Com uma estrutura básica preestabelecida, as modas de viola geralmente são compostas de uma melodia tonal cantada em terças ou sextas paralelas. Os cantadores fazem o dueto de vozes à capela ou com o acompanhamento da viola caipira dobrando as vozes da melodia. Entre uma estrofe e outra a viola caipira sempre faz os interlúdios instrumentais chamados repique ou recortado como transição entre as partes cantadas da narrativa. As estrofes cantadas e esses interlúdios instrumentais feitos na viola são as únicas partes fixas e imprescindíveis em uma moda de viola, embora ela possa possuir outras partes em sua estrutura, consideradas móveis ou opcionais, ${ }^{1}$ ficando a critério do compositor ou do intérprete incluir ou não essas partes durante a cantoria.

Rosa Nepomuceno (2005, p.69) observou que, "de toda essa mistura cultural e rítmica, a expressão musical mais típica do caipira ficou sendo a moda de viola. Parte do catira que ganhou vida própria [...]. Seus versos contaram a história do Brasil, documentaram os preconceitos sociais, os problemas políticos, as crises do café e as modificações culturais”. Em meio a essas modificações culturais, a moda de viola foi o gênero da música caipira que mais conseguiu manter suas estruturas tradicionais, tanto na dimensão musical e instrumental quanto na temática e textual, sendo sobre o caráter de permanência dessas características tradicionais que este artigo traz alguma contribuição.

\section{A moda de viola no século $\mathrm{XX}$ : entre o registro escrito e fonográfico}

Logo no início do século XX a moda de viola passou a ser objeto de registro folclórico, antes mesmo dos pioneiros registros fonográficos de outubro de 
1929. Na área dos estudos folclóricos, os primeiros registros de modas de viola provavelmente foram realizados pelos primos Amadeu Amaral (1875-1929) e Cornélio Pires (1884-1958) na passagem do século XIX para o século XX. Cornélio Pires iniciou o registro de material folclórico provavelmente em 1907, tendo publicado em 1910 uma série de artigos intitulados "Poetas caipiras" no jornal O Comércio de São Paulo, onde foram transcritas modas de viola reunidas posteriormente no livro Sambas e cateretês (1932).

Nesse ano também foi lançado o livro Tarrafadas: contos, anedotas e variedades, onde Cornélio Pires (2007, p.93) menciona algumas modas de viola que eram cantadas pelo menos desde a década de 1840, por vezes narrando acontecimentos de relevância como a Guerra do Paraguai ou a Revolução Constitucionalista de 1932. Alguns versos dessas modas de viola haviam sido cantados em 1845 pelo interior de São Paulo, tendo sido assimilados pelo modista Benedicto Gregório de Mendonça e Silva, poeta que teve uma posição de destaque dentro da obra de Cornélio Pires e que, segundo o folclorista, sabia classificar muito bem as modas que colhia daquelas que eram de sua autoria.

Alguns anos antes Cornélio Pires havia publicado os livros Conversas ao pé-do-fogo (1921) e Mixórdia (1927), onde estão registradas modas de bicho, modas trágicas, modas de namoração, modas de jogo, modas de acontecimentos, modas de italianos e modas de valentia. Entre esses registros de 1927 está a moda de viola Mecê diz que vai casá (Pires, 2008, p.164-5), gravada em fonograma dois anos depois e lançada em outubro de 1929 pela gravadora Columbia na "Série Cornélio Pires", ano esse que marca precisamente a transição entre os registros escritos e fonográficos das modas de viola.

O principal incentivador para que Cornélio Pires tenha dedicado boa parte de sua vida ao registro e resgate da cultura tradicional paulista foi seu primo Amadeu Amaral, que o alertou para as potencialidades de um campo de estudos ainda pouco explorado e o encorajou a lançar seu primeiro livro em 1910, intitulado Musa caipira. Nascido em uma fazenda no município de Monte Mor, Amadeu Amaral foi o primeiro intelectual a produzir de forma sistemática trabalhos dedicados à cultura tradicional paulista, ainda sob o rótulo de estudos folclóricos. Tendo atuado a partir de $1899 \mathrm{em}$ diversos jornais que foram decisivos para sua formação intelectual, dentre os quais o Correio Paulistano e O Estado de S. Paulo, foi neste último que publicou os primeiros rodapés intitulados "Tradições Populares", que constituíram o livro homônimo que figura como sua principal obra. Embora tenha começado a se interessar pelos estudos folclóricos por volta de 1916, tendo dado a eles um caráter mais metódico a partir de 1920, é provável que seus primeiros registros tenham sido realizados ainda no final do século XIX, muito antes de suas obras de grande envergadura sobre o folclore e a cultura popular paulista. Em sua obra figuram modas de amor, modas de bichos, modas de boi, modas de fantasia, entre muitos outros temas colhidos em cidades do interior de São Paulo e Minas Gerais. 
O amor é que fornece tema para a maioria dessas composições; mas também cantam elas em vários tons as misérias do pobre campónio, cantam as aventuras e trabalhos, cantam os mais diversos acontecimentos da vida social, observados pelo cantador. E há também as modas de pura fantasia e brincadeira, como esta que ouvi cantada por um caipira dos arredores desta cidade e que é, indisputavelmente, bem tecida. [...] São muito frequentes os cantos de índole impessoal sobre assuntos gerais da vida e da sociedade, sobre as misérias da gente humilde, sobre as desigualdades e injustiças da fortuna, sobre a morte, sobre os costumes. (Amaral, 1982 p.72 e 113)

Uma moda de viola que se tornou recorrente nos registros folclóricos foi colhida por Amadeu Amaral (1982, p.74-6 e 204-6) em 1921 na cidade de São Sebastião da Grama (SP), com o nome “As queixas do boi”. Segundo o informante Pedro Saturnino, essa moda de viola também seria muito conhecida em Minas Gerais, além do parentesco que o próprio Amadeu Amaral estabelece entre ela e algumas narrativas da região Nordeste. Na década de 1970 Rossini Tavares de Lima (1971, p.104-7) fez um levantamento dos parentescos dessa moda de viola nas cidades de Santo Amaro (SP) e em uma região próxima à Ilha do Bananal (TO), em 1952, e na cidade de Porto Feliz (SP), em 1953, com os nomes "Moda do Terneirinho", "Terneirinho" e "Boizinho que nasceu no mês de maio".

Depois, em 1925, Americano do Brasil publicou uma versão com o nome de Boi Amarelinho, recolhida em Goiás; e em 1941, outro fragmento goiano foi divulgado por José A. Teixeira, sob o título de Du Bizerru. Em 1946, surgiu documento recolhido por Lucas A. Boiteux, em Serra, no Estado de Santa Catarina, e posteriormente, em 1949, uma variante de Montes Claros, em Minas Gerais, anotada por Angélica Rezende Garcia como pisquim ou pasquim e denominada: O Bezerro do Mês de Maio, e em 1950, uma de Maria de Lourdes Henriques, cantada no Boi-de-Mamão de São Francisco do Sul, em Santa Catarina. Por fim, Rossini Tavares recolheu e publicou duas versões: uma de São Paulo e outra de Bragança Paulista, em 1951 e 1958. Em 1970, José Baptista dos Santos divulgou documento registrado no Estado do Rio. (Tavares de Lima, 1971, p.103)

Na década de 1980 Rossini Tavares de Lima (1997, p.69-72) apresentou novos registros dessa mesma moda de viola, colhida agora nas cidades de Santo Amaro (SP), em 1953, São Bernardo do Campo (SP), em 1956, e em São Francisco (MG), em 1980, com os nomes "Ramalhete", "Moda do Boizinho" e “O Boi Amarelinho". A versão fonográfica dessa moda de viola foi gravada por Raul Torres e Ascendino Lisboa em 1933 com o nome "Boi Amarelinho” (disco 33.730-A da gravadora Victor), tendo sido o próprio Raul Torres quem assinou sua autoria, e Ascendino Lisboa quem assinou a autoria da moda "Prá mode namoração", que compunha o outro lado do disco. Em 1958 Raul Torres voltou a gravar essa moda de viola no álbum Cavalo Zaino, agora pela Chantecler, acrescentando duas novas estrofes e desta vez em parceria com o cantador Florêncio. 


\section{As recorrências discursivas e os estereótipos nas modas de viola}

Ao que tudo indica, existe entre compositores caipiras um repertório de padrões e esquemas discursivos previamente estabelecidos cuja recorrência pode ser verificável a partir de análises comparativas, de forma que o processo criativo das modas de viola pode ser interpretado como resultado de diferentes combinações de padrões e esquemas que transitam entre os modistas. Essas recorrências discursivas são observadas tanto nas dimensões poética, textual, estrófica e prosódica das modas de viola quanto em sua dimensão musical, de onde decorrem estereótipos, personagens, lugares-comuns e outros elementos próprios do imaginário e cotidiano caipira. Amadeu Amaral (1982, p.134) já havia interpretado as poesias caipiras como variante de poesias populares vindas da Europa: “A 'poesia popular', em sentido lato, como a semiliterária (e como, numa esfera mais vasta, a puramente literária), abrange um fundo tradicional, coletivo, feito de ideias e de formas transmitidas, e um coeficiente de invenção pessoal". Sobre esse fundo tradicional e coletivo de ideias, Peter Burke (2010, p.173) observou na tradição europeia que:

A cultura popular pode ser descrita como um repertório de gêneros, mas também, num exame atento, como um repertório de formas (esquemas, motivos, temas, fórmulas), quer se restrinjam a um único gênero ou sejam partilhadas por dois ou mais. A tese da presente seção é que as canções e contos folclóricos, as peças e estampas populares têm que ser consideradas como combinações entre formas elementares, como permutações de elementos mais ou menos prontos. Esse ponto pode ser mais facilmente ilustrado no caso da música, meio que mais se aproxima da forma "pura".

Na canção narrativa europeia, por exemplo, Burke (2010, p.177) observou que

[...] abundam os epítetos, e os adjetivos se associam regularmente a determinados nomes, tanto numa só balada como de modo mais geral. Pense-se no "valente Douglas" em Child [...], nos "alegres rapazes" de Robin Wood, no "orgulhoso xerife" de Nottingham, ou nos muitos heróis e heroínas com "cabelos louros" ou um "corcel branco leitoso" [...]; nas baladas russas, as mãos são "alvas", os cavalos "bons", os rios "rápidos", e assim por diante.

Peter Burke chamou essas recorrências temáticas e de personagens de $l u$ gares-comuns, onde narrativas diferentes são, no fundo, uma mesma narrativa.

A analogia com gêneros da música caipira e especificamente com as modas de viola fica evidente se observamos seus personagens estereotipados: o rico boiadeiro que chega maltrapilho em um restaurante de luxo e sempre é maltratado pelos presentes; o caboclo sempre disposto a dar a vida pela mulher amada; o mineiro que sempre ganha suas apostas e demandas; as almas que voltam do além para ajudar os companheiros em perigo; o migrante que sempre se arrepende da querência deixada para trás em busca de uma vida melhor na cidade 
grande; as moças de família rica que nunca se casam com os caboclos, que por sua vez sempre dão a volta por cima, entre outros temas. Nas modas de viola todos os bois são heróis, os boiadeiros são valentes e corajosos, os caboclos são honestos e honrados e as almas sempre voltam do reino dos mortos.

\section{Alguns personagens e temáticas através do tempo: a análise comparativa}

A análise comparativa nos permite observar a existência de muitas semelhanças entre temas e personagens das modas de viola e outros presentes em antigas narrativas populares: situações, lugares, animais e fatos fantásticos podem se apresentar de forma recorrente entre gêneros narrativos da cultura popular. Nas modas de viola observamos grande ambivalência entre suas temáticas e personagens, pois ao mesmo tempo que pertencem ao imaginário caipira, elas também podem possuir uma intrínseca relação com temáticas e personagens presentes em narrativas populares de origem mais remota.

$\mathrm{Na}$ balada europeia, por exemplo, existem temas e personagens cuja recorrência pode ser claramente identificada em algumas modas de viola, a exemplo de "um ou outro conto popular italiano [que] apresenta um nobre que se casa com uma moça pobre e a abandona, ou um opressor que é levado à justiça depois de certa dificuldade" (Burke, 2010, p.218). Essas temáticas e personagens estão presentes nas modas de viola "Caboclo na cidade" e "A volta que o mundo dá", no primeiro caso, e em "Boiadeiro valente" e "Laço justiceiro", no segundo caso. Outro exemplo é o conto "Reencontro inesperado" presente no almanaque oitocentista Caixa de tesouros do amigo renano das familias, de autoria do poeta alemão Johann Peter Hebel (1760-1826). Esse conto narra a história de um rapaz que morre na véspera de seu casamento e, no entanto, sua noiva se mantém fiel a ele mesmo depois de sua morte. Esse é outro tema bastante recorrente na música caipira, a exemplo da história narrada na moda de viola "Catimbau".

Uma interpretação que visa compreender a forma como se constituiu o discurso e a textualidade temática dentro do imaginário caipira deve nos permitir aproximar as modas de viola desses antigos gêneros populares. A análise que se segue se detém sobre três temáticas presentes em antigas narrativas populares que têm como personagens principais o berói boi, o diabo e o homem justo, cuja recorrência temática aparece nas modas de viola "Herói sem medalha", "A moça que dançou com o diabo" e "Nelore valente".

\section{O herói boi do caipira brasileiro em uma festa popular renascentista}

Antes mesmo dos primeiros registros fonográficos de modas de viola onde o boi figura como personagem principal, Amadeu Amaral já havia realizado a análise de Um ciclo de romances rústicos onde predominavam Romances de vaqueiros e de bois. Intitulados desde longa data de romances nas regiões Norte e Nordeste, foi através de um Romance de boi que Amadeu Amaral (1982, p.203) 
ouviu pela primeira vez o termo moda: "Aqui vai, nos seu vestiário pouco elegante, o romance colhido em São Sebastião da Grama [SP]. 'Moda' ouvi-o eu nomear. Com efeito, para o caipira de São Paulo, toda composição em versos e cantada é "moda"'.

A exaltação do herói boi é um dos temas mais recorrentes nas modas de viola, tendo em vista que na cultura caipira o boi geralmente é bastante valorizado pelo papel que desempenha nas atividades cotidianas das comunidades rurais: auxilia a transportar objetos e mercadorias com o carro de boi, ajuda o arar da terra onde será feita a lavoura, serve como tração em engenhos e moendas, entre outras atividades. Há ainda quem diga que existem casos em que o boi vem a ser considerado como membro da família, dotado de nome, sobrenome, e sendo até incluso por alguns fazendeiros em seus testamentos de partilha de bens. É esse emblemático personagem que substitui o herói homem nas modas de viola, salvando vidas e demonstrando atos de nobreza, coragem e valentia.

Essa transferência do papel de herói do homem para o boi também foi observada por Romildo Sant'Anna (2000, p.302) em seu estudo sobre a poesia e o cantar caipira, e justificada pela personalidade do caipira brasileiro:

[...] tímidos, honestos, solidários no ideal de companheirismo, compenetrados, amorosos, pouco falantes, parece que saídos de uma foto real. Talvez a timidez de não ostentar vantagens se transfira para a procriação de um tipo semelhante a si mesmo, correlato no temperamento que faz jus reflexivo a seu próprio espírito: o herói boi.

Modas de viola como "Boi soberano", "Boi veludo", "Boi sete ouro", "Boi cigano", “Boi palácio”, "Nelore valente”, "Travessia do Araguaia”, "Herói sem medalha", entre tantas outras que exaltam o animal, refletem essa transferência dos atos de coragem e valentia para o boi em detrimento do próprio caipira. Romildo Sant'Anna (2000, p.286-7) justifica tal transferência pelo fato de que

[...] os protagonistas caipiras são geralmente encolhidos, retraídos, parece que premeditadamente imbuídos da derrota que os apavora e desanima, e de um perene sentimento trágico da vida. Por essa razão, muitas vezes são patéticos, são agônicos, são picarescos e quixotescos. Isto explica o fato de serem mais frequentes no cantar caipira as sagaranas de um herói boi do que do herói gente.

No entanto, muito antes de estar presente nas modas de viola e no imaginário do caipira brasileiro, o berói boi já estava presente na cultura popular renascentista, com o mesmo caráter mítico, renovador e salvador com que aparece nas narrativas das modas de viola, sendo bastante exaltado pelo povo nas festas populares. Uma referência a esse caráter glorioso do boi em uma festividade popular do Renascimento foi apresentada por Mikhail Bakhtin em seu estudo sobre a obra de François Rabelais, onde o autor cita sua importância em uma festa popular, assim como seu caráter de reprodução e salvação. 
Na célebre nomenclatura dos duzentos e dezesseis jogos aos quais se dedica Gargantua (Liv. I, cap. XX), há um que se chama o jogo do "boi violado". Em algumas cidades da França havia um costume, conservado até quase a época moderna, de durante o carnaval (isto é, quando se autorizavam o abate dos animais e o consumo da carne, assim como o ato carnale as bodas interditas durante o jejum) conduzir-se um boi gordo pelas ruas e praças da cidade numa procissão solene, ao som da viola, donde o seu nome de "boi violado". Sua cabeça era enfeitada de fitas multicores. Infelizmente ignoramos em que consistia exatamente o jogo. Pensamos que deveria haver certamente alguns socos. Pois esse boi violado, destinado ao matadouro, era a vitima do carnaval. Era o rei, o reprodutor (encarnando a fertilidade do ano) e ao mesmo tempo a carne sacrificada, que ia ser golpeada e cortada para fabricar salsichas e patês. (Bakhtin, 2008, p.176, grifo do autor)

Nessa passagem, além da evidente caracterização do boi enquanto rei, reprodutor e símbolo de fertilidade, há também uma curiosa e interessante relação entre o boi e a viola, pois o animal era conduzido pelas ruas e praças da cidade ao som do instrumento, de onde podemos conjecturar a existência de uma relação histórica entre essa festividade renascentista, o protagonismo do boi em uma grande quantidade de narrativas caipiras e a utilização da viola caipira como instrumento de acompanhamento nas modas de viola.

Mikhail Bakhtin (2008, p.184) diz que "em cada indivíduo surrado e injuriado, Rabelais discerne o rei, um ex-rei ou um pretendente ao trono", sendo essas algumas das características tanto do boi renascentista quanto do boi presente nas modas de viola: "A destruição e o destronamento estão associados ao renascimento e à renovação, a morte do antigo está ligada ao nascimento do novo; todas as imagens são concentradas sobre a unidade contraditória do mundo que agoniza e renasce" (Bakhtin, 2008, p.189). Para fins de comparação, vejamos a narrativa da moda de viola "Herói sem medalha", na qual podemos identificar a relação entre o rei boi renascentista e o berói boi do poeta caipira.

\section{Herói sem medalha (1984) \\ Francisco Gottardi (Sulino)}

Sou filho do interior

Do grande estado mineiro

Fui um herói sem medalha

Na profissão de carreiro

Puxando tora do mato

Com doze boi pantaneiro

Eu ajudei desbravar

Nosso sertão brasileiro 
Sem vaidade eu confesso

Do nosso imenso progresso

Eu fui um dos pioneiros

Veja como o destino

Muda a vida de um homem

Uma doença malvada

Minha boiada consome

Só ficou um boi mestiço

Que chamava Lobisome

Por ser preto igual carvão

Foi que eu pus esse nome

Em pouco tempo depois

Eu vendi aquele boi

Pros filhos não passar fome

Aborrecido com a sorte

Dali resolvi mudar

E numa cidade grande

Com a família fui morar

Por eu ser analfabeto

Tive que me sujeitar

Trabalhar no matadouro

Para o pão poder ganhar

Como eu era um homem forte

Nuqueava gado de corte

Pros companheiros sangrar

Veja bem a nossa vida

Como muda de repente

Eu que às vezes chorava

Quando um boi ficava doente

Ali eu era obrigado

Matar a rês inocente

Mas certo dia o destino

Me transformou novamente

Um boi de cor de carvão

Pra morrer na minhas mãos

Estava na minha frente 
Quando eu vi meu boi carreiro

Não contive a emoção

Meus olhos encheram d'água

E o pranto caiu no chão

O boi meu reconheceu

E lambeu a minha mão

Sem poder salvar a vida

Do boi de estimação

Pedi a conta e fui embora

Desisti na mesma hora

Desta ingrata profissão

Nessa moda de viola o boi é vendido ao matadouro para garantir o sustento da família que passava por necessidades, assumindo assim as características de reprodução, fertilidade e renovação, sendo posteriormente assassinado, tal como acontece em muitas outras modas de viola. Da mesma forma, o boi renascentista é morto para que sua carne servisse para fabricar salsichas e patês para alimentar o povo. Mikhail Bakhtin $(2008$, p.194) também ressalta a importância do boi na cultura popular medieval e renascentista através do banquete descrito na obra rabelaisiana, onde o animal igualmente representa fertilidade e grande abundância: "Assim, o banquete tem um caráter muito amplo, quase universal (não se deve esquecer que haviam matado 367.014 bois). É a 'boa mesa"”.

\section{O diabo como personagem universal da cultura popular}

Outro personagem que aparece de forma significativa nas narrativas das modas de viola e no imaginário caipira de forma geral é o diabo, sendo muitas vezes associado àquelas pessoas que buscam em simpatias e pactos demoníacos meios para se tornar um exímio violeiro. Existem inúmeras referências ao diabo nas narrativas populares, sendo facilmente encontrados registros sobre sua aparição na cultura popular antes mesmo da Idade Média. No caso específico da cultura popular medieval, Peter Burke (2010, p.99) observa que sua figura geralmente vem associada à das bruxas e dos ilusionistas, já que “a imagem da bruxa corrente nos séculos XVI e XVII envolvia elementos populares, como a crença de que certas pessoas tinham o poder de voar pelos ares ou de fazer mal aos seus vizinhos por meios sobrenaturais, e elementos eruditos, notadamente a ideia de um pacto com o diabo". Acrescenta Burke (2010, p.134) que, tanto na Idade Média quanto no Renascimento, “às vezes também se acreditava que os atores e atrizes tinham um pacto com o demônio, considerado o grande mestre do ilusionismo".

A ideia de um pacto com o diabo é uma das principais associações que se fazem no universo da cultura caipira quando o assunto é se tornar um exímio tocador de viola, no sentido mesmo de se ter uma relação muito íntima e pessoal com 
ele. Na cultura caipira, principalmente a relação que o violeiro estabelece com o diabo é muito próxima àquela dos artistas medievais e renascentistas, diferente daquela que vigorou no romantismo.

A maneira como é tratada a personagem do diabo faz também ressaltar a diferença entre os dois grotescos. Nas diabruras dos mistérios da Idade Média, nas visões cômicas de além-túmulo, nas lendas paródicas e nos $f a$ bliaux, etc., o diabo é um alegre porta-voz ambivalente de opiniões não oficiais, da santidade ao avesso, o representante do inferior material, etc. Não tem nada de aterrorizante nem estranho [...]. Às vezes, o diabo e o inferno são descritos como meros "espantalhos alegres". Mas no grotesco romântico, o diabo encarna o espanto, a melancolia, a tragédia. $\mathrm{O}$ riso infernal torna-se sombrio e maligno. (Bakhtin, 2008, p.36)

Em estudo sobre narrativas de pactos demoníacos no norte e noroeste mineiros, Luzimar Paulo Pereira (2008, p.380) observou que "as narrativas sobre pactos com o diabo são importantes tópicos da vida musical, social e religiosa dos tocadores de viola de dez cordas no norte e noroeste de Minas Gerais". Ainda que o diabo seja considerado um exímio cantador e tocador de viola no universo caipira, nas narrativas populares ele não aparece somente como mediador entre violeiros que buscam o virtuosismo técnico no instrumento, mas também como excelente dançarino.

São esses atributos que aparecem nas narrativas populares que têm como tema a moça que dançou com o diabo. Romildo Sant'Anna (2000, p.144) diz que "o tema da moça pecadora que dançou com o capeta é frequente nos folhetos de cordel nordestinos. Há inúmeros deles, como O Grande Exemplo da Moça que Foi ao Inferno por Disfazer da Mãe Dela e Zombar de Frei Damião, de Gilberto Severino Francisco, A Moça que Dansou com Satanaz no Inferno e Estória de Marieta, A Moça que Dançou no Inferno, de José Costa Leite". Uma moda de viola que traz essa temática é "A moça que dançou com o diabo", de autoria de Teddy Vieira e Jayme Ramos, a qual Romildo Sant'Anna supõe ter sido adaptada de uma moda caipira oitocentista, conforme informação obtida de Vieira, ou mesmo de um dos referidos folhetos de cordel nordestino. Com o nome "Vô contá o que aconteceu", essa mesma moda de viola foi colhida no município de Capão Bonito por Rossini Tavares de Lima (1972, p.210-12) em 1954, sendo seu informante o Sr. Antonio Thomé Pinto, que a aprendeu próximo ao município de Guapíra em 1941.

A figura do diabo também aparece em uma narrativa do catolicismo popular que foi recolhida por Oswaldo Elias Xidieh na fazenda do Sr. Antenor Brandão em 1946, na cidade de Taiúva. Contada por um caboclo mineiro chamado Arcelino Lopes, no dia de São João, essa narrativa contém pequenas alterações em relação àquelas dos folhetos de cordel e das modas de viola citadas, embora seu conteúdo seja praticamente o mesmo: o diabo aparece em uma festa de moça de família e impressiona os convidados com suas habilidades artísticas de dançarino e tocador de viola, desaparecendo logo em seguida. 


\section{Registro escrito}

Vô contá o que aconteceu

$\mathrm{Na}$ cidade de $\mathrm{S}$. Carlos,

Isto foi cuntecimento,

Foi na semana passada;

Vô contá êsses versinho

Vô explicá bem explicado.

Numa ocasião de gente rica

Uma moça dançô cô diabo.

Pai e mãe dela falou:

Este baile num tá usado,

Isto é fim de Quaresma,

Isto pode ser pecado,

Mas a moça respondeu,

Com um arzinho entusiasmado:

Ai, Jesus Cristo está no céu, Aqui nós dançamo largado.

O baile começo

Mais ou meno às nove hora,

Lá que chegou o mocinho,

Repisando um par de espora

Dando adeus prôs senhoris

Dando viva prás senhóras:

Eu quero conhecê a festera

Porque eu vô chegano agora.

O mocinho que chegô

Era mais do que um dotô,

Cheio de aliança no dedo,

Anel que furtava côr;

Moça pra dança com ele

Pedia até por favor:

Eu quero dançá com voce

Eu quero sê o seu amor.

O moço tirô a moça, $\mathrm{Na}$ sala saiu dançando, Danço valsa e mazurca, No salão saiu rodando,
Com o chapéu na cabeça,

A moça foi se incomodando:

$\mathrm{Ai}$, você tá fora do uso,

E a mamãe não tá gostano.

Tirô o chapéu da cabeça, Os dois chifres the mostrou, Chifre de boi cuiabano, Daquele bem pegadô;

A moça quando viu isso, Noutra vida ela passô.

Ai, por sê moça de corage

Até o diabo ela enfrentô.

Deu um estouro na sala, Foi só enxofre que cheirô;

$\mathrm{Ai}$, eu tenho a certeza

Que a moça o diabo levô;

A sala tava tão clara, Ficô escura que nem breu.

O diabo saiu dizendo:

Tudo esse pessoal é meu.

Vô cantá êsses versinho,

Vô fazê explicação:

Isto serve de exemplo

Quem abusa religião,

Deixar a lei de Deus,

Frequentá outras diversão.

E acabô-se a moça rica

Filha do Major-Simão! 
A moça que dançou com o diabo (1953)

\section{Teddy Vieira / Jayme Ramos}

Numa sexta-fêra santa

Há muitos ano atrás

Na cidade de São Carlo

Tirô o chapéu da cabeça

Pubricarô nos jornais

Uma moça muito rica

E os dois chifre ele mostrô

Contrariô o gosto dos pais

Parecia um toro véio

Num baile que fez em casa

Daquele mais pegadô

Ela dançô co Satanáis

Quando o baile começô

O diabo sortô um bufo

E sumiu numa explosão

Praquela gente sem fé

Isso serviu de lição

Regulava nove hora

No meio da correria

Chegô um moço bem vestido

Dois gritô em confusão

Arrastando um par de espora

Dando viva para o povo

Ficô loca a moça rica

Fia do Major Simão

Como vai minha senhora?

Quero conhecê a festêra

Porque eu tô chegando agora

O véio disse pra fia

Hoje o baile tá mudado

Tâmo no fim da Coresma

Isto pode sê pecado

A mocinha respondeu

O senhor que tá cismado

Jesus Cristo está no céu

E nóis aqui dança largado

Pegâno na mão da moça

O moço saiu dançâno

Tocava varsa e mazurca

O cabra tava virâno

Com o chapéu na cabeça

A moça foi incomodâno

O senhor dança direito

Que mamãe não tá gostâno

Ele foi disse pra moça

Minha hora já chegô

Eu preciso ir-me embora

Que o galo já cantô 
- Certa feita, lá pras bandas de Treis Coração, o diabo escuitô dizê que ia ter baile na fazenda do... ara, não lembra mais de quem. Mais, como ocê sabe, o diabo é violeiro e dançadô de baile, pois num vê que ele se arvoroçô e, mais do que depressa, disse: - Vô me arrumá, pegá meus trem, uai, e vô! - Dito e feito, o cujo esfregou capim de cheiro no corpo, escondeu o chiframe com chapelão de boiadero, botô uma pala bem comprida pra escondê os cambito, os casco e o rabo, afinou a viola e desembesto pelo estradão. Chegando lá, a função já tinha começado e o demo já foi se enfiano no meio do povo e, pra chamá atenção dos outro, ele arrancô da viola um ponteo que era uma beleza de se escuitá. O povo foi se achegano e ele virô dono da festa. Antão, ocê sabe, o burro fica véio, perde o pêlo, mais num perde a barda, pois num vê que o diabo se inxeriu de orgúio e garrô a dar pinote de cá pra lá, e fazia corta-jaca, e fazia galeo de fandango, e sapateava catira, e o dizia que aquele ali era o maiô violero e o maiô dançadô. Mais, como Deus tarda mais num faia e mentira tem perna curta e num mora no fundo do poço, o castigo chego. Foi ansim:

O diabo tanto feiz, tanto suô, que sua morrinha de cão e seu pitiú de pexe podre tresandô; tanto que cairo o chapeulão e a pala e aparecero as guampa, os cambito e os casco dele e mais o rabo. Foi antão que os muleque, e ocê sabe que minino é pior que o cusarruim, vendo aquela corrução, puxaro o rabo dele, caçoaro dos casco, do chifre de vaca e da barba de bode dele, cataro uns chuço de pau e cairo no coro dele vê marimbondo, e, catuca daqui e catuca dali, o tar num güentô, perdeu a pala, perdeu a viola, perdeu a prosa e disparô que ninguém viu:

Apois, tava ele de cocre em riba de um cupim passano cuspe nas quebradura e mascano foia de carrapatera pra-mor-dos miudo pisado e chego um home muntado num pangaré e o home disse:

- Bas noite, cumpadre, si mar no le pregunto, descansandinho?

- Quar-o-que! Tô doente, cumpadre, e será que o cumpadre pode me dar garupa?

- Ara, vá muntano, num se avexe, se ajeite que dejagorica mermo nois chega ali na fazenda da festa, bamo!

- Beco! Berro o diabo, vai lá não, cumpadre, que‘sta ansim de mulecadas! (Xidieh, 1993, p.135)

\section{O catolicismo popular e a personagem do bomem justo que é condenado}

Algumas temáticas e personagens do catolicismo popular também são bastante recorrentes nas modas de viola, em especial aquelas com teor pedagógico que exaltam a humildade e generosidade como valores morais e de conduta a ser seguido e praticado. Nessas narrativas, Jesus Cristo aparece disfarçado de mendigo para testar a humildade e a bondade das pessoas, geralmente pedindo um pouso, um copo de água ou um pedaço de pão na porta das casas: “o santo disfarçado em peregrino ou mendigo, Deus, alguém para experimentar a bondade humana, o Cristo andejo, o andante, vira-mundo, vindo não se sabe de onde, e 
que, carregado de dons e poderes sobrenaturais, pode recompensar ou castigar seus hospedeiros" (Xidieh, 1993, p.84).

No caso das modas de viola existe uma pequena variação que consiste na troca de personagem onde, ao invés de ser o próprio Jesus Cristo quem surge para colocar em prova a humildade e a bondade das pessoas, é o rico fazendeiro ou boiadeiro de grandes posses quem surge sujo e maltrapilho e acaba sendo maltratado, rechaçado e até expulso dos lugares. Há um grande número de modas de viola que trazem essa temática, como "O rei do gado", "Exemplo de humildade" e "Terra Roxa", onde o personagem principal é um viajante misterioso e desconhecido que entra em um restaurante com trajes sujos e ares de andarilho e, após ser maltratado e ofendido pelos presentes, revela sua posição de rico fazendeiro e homem de grandes posses.

De certa forma, essas narrativas tratam do personagem que, mesmo sendo justo e inocente, acaba sendo julgado e condenado, em uma evidente analogia à crucificação de Jesus Cristo. A narrativa $O$ espinho da coroa de Jesus, recolhida na cidade de Poá por Oswaldo Elias Xidieh, é um exemplo dentre várias narrativas que trazem esta temática.

\section{O espinho da coroa de Jesus}

Quando Jesus Cristo ia arrastando a cruz, morro acima, a coroa de espinhos que the deram caiu no chão e soltou um espinho. Um homem de muita piedade catou o espinho, que estava molhado de sangue, e guardou no lenço. Naquele mesmo dia o filho do rei que mandou matar Jesus ficou muito doente e ninguém podia curá-lo.

Então, o homem foi lá e deu um cutucão no braço do menino com o espinho de Jesus e o menino, na mesma hora, sarou e pulou da cama.

- "Que virtude tem esse espinho, meu bom homem?" perguntou o rei.

- "A virtude desse espinho é o sangue daquele homem justo que você mandou matar", respondeu o homem. (Xidieh, 1993, p.68-9)

A comparação que fazemos aqui é com a moda de viola "Nelore valente", que narra a história de um fazendeiro que teve seu filho salvo pelo próprio boi que ele havia mandado matar quando era bezerro. Além da mencionada temática do personagem justo e inocente que é julgado e condenado de forma injusta, temos também o protagonismo e a importância dada ao herói boi, que na variação desta narrativa desempenha o mesmo papel que Jesus Cristo.

\section{Nelore valente (1986)}

Sulino / Antônio Carlos da Silva

$\mathrm{Na}$ fazenda que eu nasci

Vovô era retireiro

Bem criança eu ajudava

Prender o gado leiteiro 
Um dia de manhã cedo

Veja só que desespero

Tinha um bezerro doente

A ordem do fazendeiro:

- "Mate já este animal

E desinfete o mangueiro

Se essa doença espalhar

Poderá contaminar

O meu rebanho inteiro".

Eu notei que meu avô

Ficou bastante abatido

Por ter que sacrificar

$\mathrm{O}$ animal recém-nascido

Nas lágrimas dos seus olhos

Eu entendi seu pedido

Pus o bichinho nos braços

Levei pra casa escondido

Com ervas e benzimentos

Seu caso foi resolvido

Com carinho eu lhe tratava

E o leite que o patrão dava

Com ele era dividido

Quando o fazendeiro soube

Chamou o meu avozinho

Disse você foi teimoso

Não matando o bezerrinho

Vai deixar minha fazenda

Amanhã logo cedinho

Aquilo feriu vovô

Como uma chaga de espinho

Mais há sempre alguém no mundo

Que nos dá algum carinho

E sem grande sacrifício

Vovô arranjou serviço

Ali no sítio vizinho

Em pouco tempo o bezerro

Já era um boi erado

Bonito forte e troncudo 
Mansinho e muito ensinado

Automóvel do atoleiro

Ele tirava aos punhados

Por isso na redondeza

Ficou bastante afamado

Até que um dia à noitinha

Um homem desesperado

Gritou pedindo socorro

Seu carro caiu no morro

Seu filho estava prensado

O carro da ribanceira

$\mathrm{O}$ boi conseguiu tirar

O menino estava vivo

Seu pai disse a soluçar

Qualquer que seja a quantia

Esse boi eu vou comprar

Eu disse ele não tem preço

A razão vou explicar

A bondade do vovô

Veio seu filho salvar

Esse nelore valente

É o bezerrinho doente

Que o senhor mandou matar

\section{Considerações finais: para além de uma abordagem difusionista}

Uma das grandes preocupações dos folcloristas no começo do século XX no que diz respeito à coleta e registro de modas de viola, bem como de narrativas populares de modo geral, foi a de estabelecer paralelos com enredos narrativos mais antigos, de modo a encontrar pontos de ligação que comprovassem uma relação de parentesco e filiação. Esse foi um dos objetivos de Amadeu Amaral (1982, p.125-6), que buscou apurar a genealogia e o fundo coletivo e anônimo das narrativas populares e chegou a dizer sobre as cantorias e poesias dos caipiras paulistas que "não se sabe, em regra, nem como nem onde nasceram os versos. São repercussões de outros que já foram cantados [...]".

Oswaldo Elias Xidieh (1993, p.73-4) também procurou estabelecer a filiação das narrativas populares através de uma análise comparativa com evangelhos apócrifos, com algumas suras do Alcorão e com quadras registradas por escritores portugueses:

É nos evangelhos e nos documentos piedosos apócrifos que podemos encontrar farto e interessantíssimo material para um estudo de filiação, difu- 


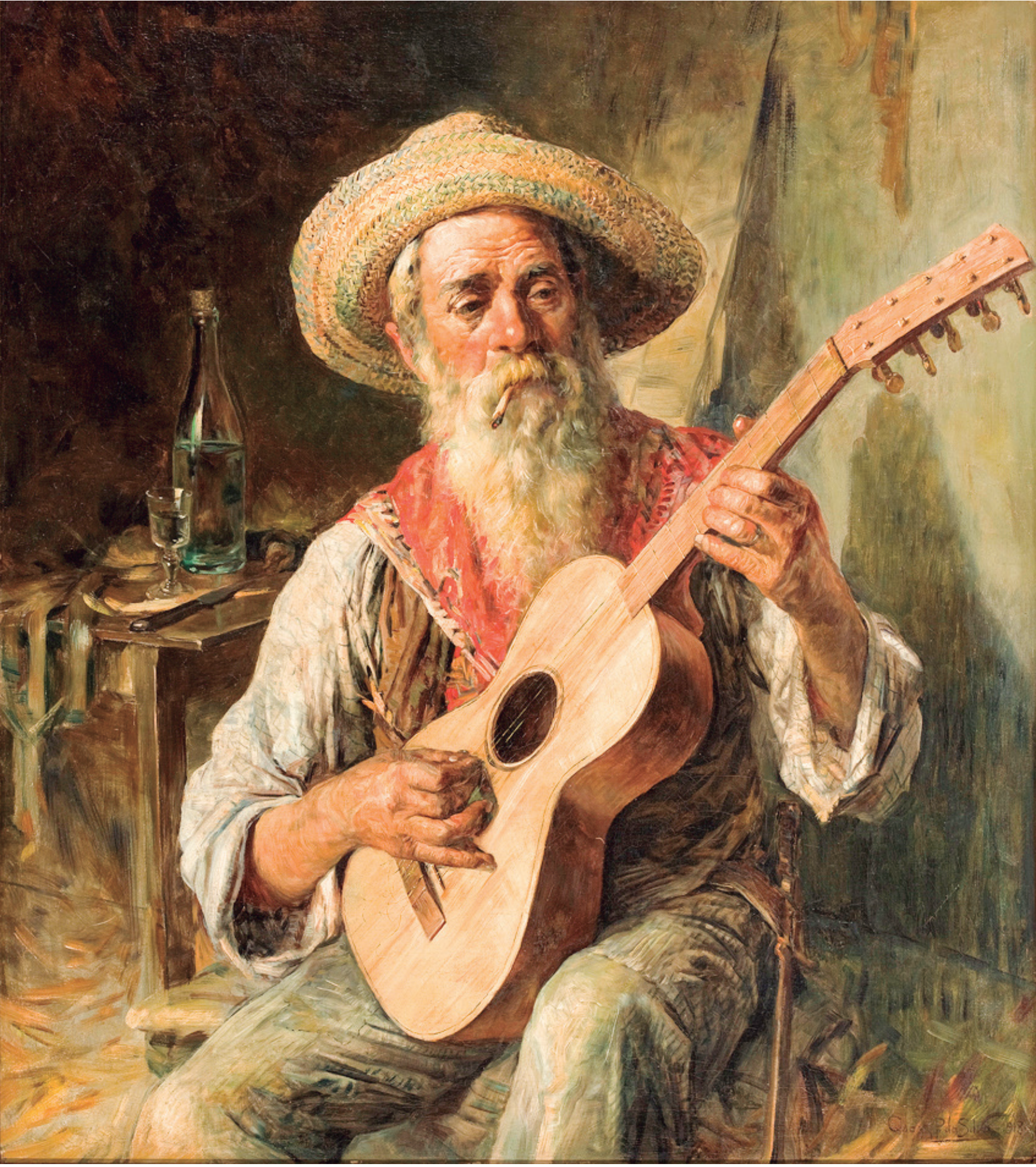

Violeiro caipira (1918), de Oscar Pereira da Silva (1865-1939). Óleo sobre tela. Acervo Banco Itaú. Fonte: Enciclopédia Itaú Cultural de Arte e Cultura Brasileiras. São Paulo: Itaú Cultural, 2017. 
são e comparação de alguns dos registros que acabamos de apresentar. [...] Pois bem, alguns dos nossos relatos filiam-se, inegavelmente, ao texto e ao espírito daquelas obras religiosas populares algumas ou, como outras, comprometidas com filosofias e crenças não cristãs.

Procurando ir um pouco além desta abordagem difusionista, cabe questionarmos os motivos que levaram à perpetuação de algumas temáticas e personagens nas modas de viola e por que suas características musicais tradicionais praticamente não sofreram alterações no decorrer do tempo, principalmente após terem sido inseridas na indústria fonográfica. Ao invés de questionarmos de onde vêm as temáticas e os personagens das modas de viola, talvez seja mais interessante nos perguntarmos como e por que eles têm sido transmitidos através de gerações e se existe alguma relação entre essa perpetuação temática e de personagens com o fato de a moda de viola ser o gênero da música caipira que menos sofreu alterações em suas características tradicionais, ainda que inserida em um dinâmico processo de transformações culturais. Cabe questionarmos se mecanismos foram e ainda são acionados pelos sujeitos para reafirmarem uma identidade tradicional em um mundo em constante transformação e se a moda de viola seria um elemento que permite aos sujeitos lidarem com a moderna contradição de se transformarem e, ainda assim, permanecerem ligados de alguma forma a uma identidade caipira tradicional.

Sendo nosso propósito aqui problematizar essa questão, talvez seja importante explorar alguns dos impasses e dilemas vividos pelos modistas e cantadores caipiras no auge da indústria fonográfica. Foi nesse período que as gravadoras passaram a exercer influência no repertório das duplas caipiras evidenciando as primeiras transformações significativas no cenário fonográfico, substituindo as músicas caipiras tradicionais por gêneros mais urbanizados e consequentemente fazendo que os cantadores caipiras acionassem novos mecanismos para reafirmarem uma identidade caipira tradicional. Em 1966, por exemplo, os irmãos Tonico \& Tinoco foram pressionados pela gravadora para gravar a música "Disparada", de Geraldo Vandré e Théo de Barros, que havia acabado de ganhar o II Festival de Música Popular Brasileira da TV Record.

A gravadora quis, por exemplo, que a gente gravasse "Disparada" depois da vitória do Jair Rodrigues no Festival. Tivemos dificuldade de aprender a música, não era nosso estilo. [...] Os diretores nos chamaram e falaram: nas próximas gravações vocês vão ter que modificar o estilo ou então gravar as modas sertanejas com letras jovens e guitarras elétricas, pois os tempos mudaram e é isso que está vendendo. Não aceitamos nenhuma das propostas e eles nos disseram que a gente não ia gravar mais. Então, rescindimos o contrato. [...] Participaram mais de 20 pessoas da empresa, entre diretores e representantes de vendas, sugerindo uma porção de coisas, e eu me lembro que falei: Então vamos parar, deixar baixar o pó, depois nóis vorta. (Tinoco apud Nepomuceno, 1999, p.189) 
Os irmãos se mantiveram durante muito tempo fiel às raízes e ao estilo caipira, recusando contratos até uma relativa e parcial adesão à nova aparelhagem eletrônica em período ainda mais recente, através da banda de Tinoco com seu filho Tinoquinho. Ainda que um aparato instrumental mais moderno tenha sido acrescentado e os arranjos tenham sofrido mudanças, o repertório continuava sendo as músicas tradicionais, com destaque para a moda de viola, que sempre era executada guardando suas características tradicionais: "Música é feito roupa, sapato. Tem moda, e se a gente não se moderniza, fica pra trás. Mas nossa raiz não muda" (Tinoco apud Nepomuceno, 1999, p.24).

Como principal símbolo de resistência da música caipira, a moda de viola possui uma dimensão responsável pela permanência de suas características tradicionais que não pode ser explicada por um suposto caráter universal de suas temáticas e personagens ou pelas relações de parentesco e filiação com arquétipos de gêneros narrativos do passado. Sendo possivelmente a principal responsável por sua perpetuação, talvez essa dimensão esteja relacionada a mecanismos identitários acionados pelos sujeitos no momento em que tomam a moda de viola como símbolo da verdadeira música caipira.

Ao invés de oferecer uma resposta para as questões apresentadas, cabe-nos aqui expor a existência de um problema a ser investigado. Contrariando os prognósticos dos estudos sobre a mundialização da cultura e sobre a interferência da indústria cultural nas culturas tradicionais, que apontavam para uma gradativa extinção ou transformação de suas manifestações, a moda de viola mantêm suas características tradicionais em meio a um processo de profundas transformações culturais. Essa constatação nos revela, de um lado, uma extraordinária capacidade do gênero em resguardar suas características mais tradicionais e, de outro, a contradição de que, apesar das inovações e das transformações ocorridas nas culturas tradicionais e na música caipira em geral, a moda de viola não se transforma e pouco se moderniza. Essa é uma grande contradição digna de ser estudada voltando-se talvez para os estudos sobre identidade, já que a moda de viola se apresenta como o gênero da música caipira capaz de imprimir nos sujeitos uma identidade que os remetem e os vinculam aos valores mais tradicionais da cultura caipira.

\section{Nota}

1 Essas partes opcionais das modas de viola são o ponteio, o levante, a catira, a declamação e o baixão. Sobre essa estrutura, consultar Faustino e Garcia (2016).

Referências

AMARAL, A. Tradições populares. 3.ed. São Paulo: Hucitec; Brasília: INL, 1982.

BAKHTIN, M. M. A cultura popular na Idade Média e no Renascimento: o contexto 
de François Rabelais. 6.ed. Trad. Yara Frateschi Vieira. São Paulo: Hucitec; Editora Universidade de Brasília, 2008.

BURKE, P. Cultura popular na Idade Moderna: Europa 1500 - 1800. Trad. Denise Bottmann. São Paulo: Cia. das Letras, 2010.

FAUSTINO, J. C.; GARCIA, R. M. da S. A série Cornélio Pires: análise da forma musical das suas modas-de-viola. Revista Debates, Rio de Janeiro, n.16, p.63-89, jun. 2016. Disponivel em: <http://www.seer.unirio.br/index.php/revistadebates/article/ view $/ 5773 / 5275>$

NEPOMUCENO, R. Música caipira: da roça ao rodeio. 2.ed. São Paulo: Ed. 34, 2005.

PAULA OLIVEIRA, A. de. O tronco da roseira: Uma antropologia da viola caipira. 2004. Dissertação (Mestrado em Antropologia) - Centro de Filosofia e Ciências Humanas, Universidade Federal de Santa Catarina. Florianópolis, 2004.

PEREIRA, L. P. A viola do diabo: notas sobre narrativas de pactos demoníacos no norte e noroeste mineiro. In: GIUMBELLI, E.; VALLADÃO DINIZ, J. C.; NAVES, S. C. Leituras sobre música popular: reflexões sobre sonoridades e cultura. Rio de Janeiro: 7Letras, 2008.

PIMENTEL, S. V. Música caipira e música sertaneja. In: O chão é o limite: a festa do peão de boiadeiro e a domesticação do sertão. Goiânia: Editora da UFG, 1997. p.187-234.

PIRES, C. Tarrafadas: contos, anedotas e variedades. Itu: Ottoni Editora, 2007. . Mixórdia. Itu: Ottoni Editora, 2008.

SANT'ANNA, R. A moda é viola: Ensaio do cantar caipira. São Paulo: Arte \& Ciência; Marília: Unimar, 2000.

TAVARES DE LIMA, R. Romanceiro folclórico do Brasil. São Paulo: Irmãos Vitale, 1971. Abecê do Folclore. 5.ed. São Paulo: Ricordi, 1972.

Moda de viola: Poesia de circunstância. Secretaria de Estado da Cultura: Comissão Estadual de Folclore. São Paulo: Laser Press Gráfica, 1997.

XIDIEH, O. E. Narrativas populares: estórias de nosso Senhor Jesus Cristo e mais São Pedro andando pelo mundo. Introd. Alfredo Bosi. São Paulo: Editora da Universidade de São Paulo; Belo Horizonte: Itatiaia, 1993.

\section{Referências fonográficas}

Mecê diz que vai casá - moda de viola. Niltinho Pinto; Intérpretes: Zico Dias \& Sorocabinha (da Turma Caipira Cornélio Pires). Gravadora Colúmbia, disco 20.008-B, lançado em outubro de 1929, matriz 380284.

Boi Amarelinho - moda de viola. Raul Torres; Intérpretes: Raul Torres \& Ascendino Lisboa. Gravadora Victor, disco 33.730-A, gravado em 23 de outubro de 1933 e lançado em dezembro do mesmo ano, matriz 65869.

A moça que dançou com o diabo - moda de viola. Jayme Ramos / Teddy Vieira; Intér- 
pretes: Vieira \& Vieirinha. Gravadora Continental, disco 16.782-A, gravado em 13 de abril de 1953 e lançado em julho-agosto do mesmo ano, matriz 11518.

Laço Justiceiro - moda de viola. Sulino / Pedro Lopes de Oliveira; Intérpretes: Sulino \& Marrueiro. Gravadora RCA-Victor, disco 80-1505-B, gravado em 17 de junho de 1955 e lançado em outubro do mesmo ano, matriz BE5VB-0788.

Boi Amarelinho - moda de viola. Raul Torres; Intérpretes: Raul Torres \& Florêncio. Álbum Cavalo Zaino. Gravadora Chantecler, disco CLP-2011-B6 (primeira prensagem) e CMG-2011-B6, gravado em 1958.

Catimbau - moda de viola. Carreirinho / Teddy Vieira; Intérpretes: Tião Carreiro \& Carreirinho. Gravadora RCA-Victor, disco 80-2016-B, gravado em 8 de outubro de 1958 e lançado em dezembro do mesmo ano, matriz 13-J2PB-0512.

Rei do gado - moda de viola. Teddy Vieira; Intérpretes: Tião Carreiro \& Carreirinho. Gravadora Continental, disco 17.544-B, lançado em maio-junho de 1958, matriz 12047.

Terra roxa - moda de viola. Teddy Vieira; Intérpretes: Tião Carreiro \& Carreirinho. Gravadora Chantecler (selo Sertanejo), disco CH-10.282-A, lançado em julho de 1962, matriz S9-563.

A volta que o mundo dá - moda de viola. Lourival dos Santos / Zé Batuta; Intérpretes: Liu \& Léu. Álbum Onde en moro. Gravadora Chantecler (selo Sertanejo), disco CH-3.009-A4, gravado em 1966 e relançado sob o número S-17028-A4.

Exemplo de humildade - moda de viola. Dino Franco / Tião Carreiro; Intérpretes: Tião Carreiro \& Pardinho. Álbum Duelo de amor. Gravadora Chantecler (selo Sertanejo), disco 2.10.407.145-B3, gravado em 1975.

Boiadeiro valente - moda de viola. Tomaz / Mato Grosso; Intérpretes: Abel \& Caim. Álbum Os Reis da moda de viola. Gravadora CID (selo Itamaraty), disco 2.067-B5, gravado em 1981.

Caboclo na cidade - moda de viola. Dino Franco / Nhô Chico; Intérpretes: Dino Franco \& Mouraí. Álbum Rancho da Boa Paz (Caboclo na cidade). Gravadora Globo, disco GGLP-019-Al, gravado em 1982.

Herói sem medalha - moda de viola. Sulino; Intérpretes: Tião Carreiro \& Pardinho. Álbum Modas de viola Classe " $A$ ” - v.4. Gravadora Chantecler / Continental, disco 1.71.405.640-A3, gravado em 1984.

Nelore valente - moda de viola. Sulino / Antônio Carlos da Silva; Intérpretes: Dino Franco \& Mouraí. Álbum Modas de viola - v,2. Gravadora Chantecler / Continental, disco 2.11.405.728-Al, gravado em 1986.

RESUMO - A moda de viola é considerada um dos gêneros mais tradicionais da música caipira, se aproximando enquanto gênero narrativo das antigas lendas medievais e dos romances de cavalaria ibéricos renascentistas, sendo ainda afluente da cultura moura. Suas temáticas são reveladoras de uma funcionalidade social que, ao transmitirem valores pedagógicos, morais e expressarem poética e musicalmente determinados contextos sociais, servem como ferramenta de denúncia e crítica a processos de exclusão e opres- 
são social. Este artigo traz uma breve descrição de seus primeiros registros coletados por folcloristas no início do século XX, dos dilemas decorrentes de sua inserção no registro fonográfico a partir de 1929 e das contradições acerca da perpetuação do gênero através dos tempos, focalizando principalmente sua potencialidade no campo dos estudos sobre identidade.

PALAVRAS-CHAVE: Moda de viola, Música caipira, Cultura popular, Tradição, Identidade. ABSTRACT - The moda-de-viola [folk guitar songs] is considered one of the most traditional genres of country music, a narrative genre approaching the old medieval legends and romances of the Iberian Renaissance when it was still an affluent of Moorish culture. Its themes reveal a social functionality that, by conveying pedagogical and moral values, and by expressing poetically and musically certain specific social contexts, serves as a tool to denounce and criticize processes of exclusion and social oppression. This article presents a brief description of the first records collected by folklorists in the early twentieth century, of the dilemmas arising from its insertion in the phonographic record from 1929 onward, and of the contradictions in the perpetuation of this genre over time, focusing mainly on its potentiality in the field of identity studies.

KErWORDs: Moda de viola, Country music, Popular culture, Tradition, Identity.

Rafael Marin da Silva Garcia é doutorando em Música e Cultura pela Escola de Música da Universidade Federal de Minas Gerais, e professor de violão popular e viola brasileira do Conservatório Municipal de Música de Alfenas, Minas Gerais. @ - rafaelmarin7@ hotmail.com

Recebido em 28.6.2017 e aceito em 17.7.2017.

I Escola de Música, Universidade Federal de Minas Gerais, Belo Horizonte, Minas Gerais. 